JURNAL JURNALISME

Program Studi Ilmu Komunikasi

Fakultas Ilmu Sosial dan Ilmu Politik

Universitas Malikussaleh
P-ISSN: 2502-048X

E-ISSN: 2807-2537

\title{
PROMOSI OBJEK WISATA PANTE PANGAH GAMPONG IERHOB KECAMATAN GANDAPURA DALAM MENINGKATKAN KUNJUNGAN WISATAWAN
}

Ekayanti $^{1}$ dan Deddy Satria $\mathrm{M}^{2}$

1. Sarjana ilmu komunikasi Universitas Malikussaleh

2. Dosen program studi ilmu komunikasi Universitas Malikussaleh

EMAIL: deddy.satria@unimal.ac.id

\begin{abstract}
ABSTRAK
Penelitian ini berjudul "Promosi Objek Wisata Pante Pangah Gampong Ie Rhob Kecamatan Gandapura dalam Meningkatkan Kunjungan Wisatawan". Lokasi penelitian Desa Ie Rhob Kecamatan Gandapura. Penelitian bertujuan untuk mengetahui tentang Komunikasi Pemasaran Objek Wisata Pante Pangah Gampong Ie Rhob dalam promosi wisata Pante Pangah di Kecamatan Gandapura Kabupaten Bireuen yang mengandung unsur element Marketing Mix 4P dan Model AIDA dan hambatan-hambatan dalam pengembangan pariwisata Gampong Ie Rhob dalam Promosi wisata Pante Pangah di Kecamatan Gandapura Kabupaten Bireuen. Metode yang digunakan dalam penelitian ini adalah metode kualitatif dengan pendekatan deskriptif. Untuk memperoleh data dan informasi yang lengkap dalam penelitian ini digunakan teknik pengumpulan data berupa observasi, wawancara dan dokumentasi. Teknik analisis data yang digunakan adalah teknik analisa data. Hasil penelitian menunjukkan bahwa pelaksanaankomunikasi pemasaran wisata Pante Pangah yang sesuai digunakan dalam promosi objek wisata yaitu menunjukkan penggunaan model A.I.D.A serta menggunakan Bauran Pemasaran. Hambatan -hambatan dalam pengembangan wisata Pante Pangah adalah kurangnya biaya untuk promosi, pemanfaatan mediapromosi dan kinerja yang belum sesuai dengan tupoksi.
\end{abstract}

Kata kunci : Promosi, wisata, komunikasi pemasaran, model A.I.D.A

\section{Pendahuluan}

Kecamatan Gandapura merupakan salah satu Kecamatan yang berada di Kabupaten Bireuen. Kecamatan Gandapura memiliki lokasi wisata yang berpotensi untuk menarik minat pengunjung yang bertempat di Gampong Ie Rhob, Gampong Ie Rhob berada di bibir pantai, wisata tersebut ialah wisata Pante Pangah. Wisata ini merupakan wisata baru yang memiliki keunikan pesona alam indah berupa suasana pantai yang indah dan juga pemandangannya. Wisata Pante Pangah merupakan salah satu wisata yang mempunyai potensi untuk dikembangkan dalam menarik minat wisatawan, karena wisatawan yang 
JURNAL JURNALISME

Program Studi Ilmu Komunikasi

Fakultas Ilmu Sosial dan Ilmu Politik

Universitas Malikussaleh
P-ISSN: 2502-048X

E-ISSN: 2807-2537

datang untuk mengunjungi wisata Pante Pangah akan disuguhkan dengan pemandangan yang indah, banyak wisatawan yang datang kesana untuk mengabadikan moment mereka dan menikmati suasana santai bersama keluarga wisata Pante Pangah juga menyediakan fasilitas umum seperti mushala, kedai kecil yang di desain sedemikian rupa disepanjang pantai Pante Pangah juga pondok yang terbuka untuk pengunjung disana juga terdapat waterboom mini untuk pemandian anak kecil. Walaupun wisata Pante Pangah baru berjalan 2 tahun yang terbilang baru sebagai tempat wisata di Kecamatan Gandapura, apabila dipromosikan dengan promosi yang tepat, wisata ini bisa menjadi wisata yang mampu bersaing dalam industri pariwisata di Aceh. Namun bagaimana cara pengelola untuk mempromosikan wisata Pante Pangah dalam menarik minat wisatawan mengingat wisata Pante Pangah ini terbilang masih baru, sedangkan pariwista di Aceh jumlahnya tidaklah sedikit. Hal inilah yang menarik penulis untuk meneliti lebih dalam tentang promosi yang dilakukan oleh pengelola wisata Pante Pangah dengan menggunakan media.

Promosi adalah suatu kegiatan yang dimaksudkan untuk mengkomunikasikan suatu produk kepada sasaran untuk memberi informasi tentang keistimewaan, yang paling penting adalah keberadaannya untuk mendorong orang-orang supaya bertindak sedangkan pariwisata merupakan salah satu kegiatan perjalan yang dilakukan secara sukarela yang bersifat sementara untuk menikmati objek dan daya tarik wisata yang mengangumkan.

Seiring meningkatnya kebutuhan masyarakat untuk berwisata, KecamatanGandapura merupakan daerah yang banyak terdapat tujuan wisata yang diinginkanmaka perlu adanya usaha pariwisata yang memungkinkan untuk dibuka dan dipromosikan, kurang terolah dan secepat mungkin dapat memberi dampak positifterhadap usaha yang dilakukan dengan berbasis kemasyarakatan. Sehingga selain memperkenalkan daerah tujuan wisata yang belum dikenal, tentu ini juga akanmempercepat terwujudnya pemerataan pendapatan dan kesempatan berusaha bagi masyarakat setempat.

Dari hasil pengamatan penulis, minimnya keahlian dalam hal merancangpromosi, kurangnya koordinasi antar beberapa pihak, serta tidak adanya komitmen kuat dari para stakeholder khususnya dalam pengembangan pariwisata mengakibatkan kurangnya 
JURNAL JURNALISME

Program Studi Ilmu Komunikasi

Fakultas Ilmu Sosial dan Ilmu Politik

Universitas Malikussaleh
P-ISSN: 2502-048X

E-ISSN: 2807-2537

informasi yang diperoleh oleh pengunjung untuk dapat mengunjungi wisata Pante Pangah.

Karena dianggap tempat wisata Pante Pangah belum bisa memberikan ketertarikan tersendiri bagi pengunjung hal inilah yang menjadi kendala dalam usaha pengembangan wisata Pante Pangah dan dapat menghambat kertarikan tersendiri bagi pengunjung. (Observasi awal, 2 maret 2019).

Semoga dengan adanya upaya yang dilakukan oleh pihak pengelola wisata dalam mempromosikan wisata Pante Pangah. Wisata ini semoga terus berkembang dan akan terus dikunjungi oleh wisatawan domestik dan mancanegara dan wisata ini dapat bersaing dengan pariwisata lainnya. Upaya yang dilakukan oleh pihak pengelola wisata Pante Pangah dalam mempromosikan sebagai wisata berupa komunikasi pemasaran yang dilakukan untuk mempromosikan wisata Pante Pangah melalui model AIDA yang termasuk kedalam bagian dari kegiatan promosi. Dalam proses promosi tersebut peneliti ingin meneliti lebih dalam tentang bagaimana komunikasi pemasaran yang dilakukan oleh pihak pengelola wisata Pante Pangah

Berdasarkan latar belakang diatas, maka rumusan masalah dalam penelitian ini adalah sebagai berikut:

1. Bagaimana komunikasi pemasaran objek wisata Pante Pangah Gampong Ie Rhob Kecamatan Gandapura Kabupaten Bireuen dalam meningkatkan kunjungan wisatawan?

2. Bagaimana hambatan-hambatan dalam pengembangan wisata Pante Pangah Gampong Ie Rhob dalam meningkatkan kunjungan wisatawan?

\section{landasan Teori}

\section{Pengertian Komunikasi Pemasaran}

Dasar pengembangan kegiatan pemasaran adalah komunikasi. Adapun pengertian komunikasi pemasaran adalah komunikasi yang dilakukan perusahaan atau lembaga baik secara tatap muka, maupun bermedia dalam rangka upaya meningkatkan penjualan jasa atau hasil produksi (Effendy, 2003:216). Menurut Kotler \& Ketler (2012:498), 
JURNAL JURNALISME

Program Studi Ilmu Komunikasi

Fakultas Ilmu Sosial dan Ilmu Politik

Universitas Malikussaleh
P-ISSN: 2502-048X

E-ISSN: 2807-2537

Mendefinisikan komunikasi adalah proses individu memberikan stimulus yang biasanya dalam bentuk verbal untuk mengubah tingkah laku orang lain. Jadi jika digabungkan semua elemen dalam bauran pemasaran, yang memfasalitasi pertukaran dengan menargetkan merek untuk sekelompok pelanggan, posisi merek yang membedakan dengan merek untuk sekelompok pelanggan, posisi merek yang membedakan dengan merek pesaing dengan menciptakan suatu arti yang disebarluaskan kepada pelanggan.

Menurut Keller (2008) dalam Abdurrahman (2015), komunikasi pemasaran adalah sarana yang digunakan dalam upaya untuk menginformasikan, membujuk, dan mengingatkan konsumen langsung atau tidak langsung tentang produk yang mereka jual. Menurut Kotler dan AB Susanto (2000), memberikan definisi pemasaran yaitu suatu proses dan manajerial dimana individu dan kelompok mendapatkan kebutuhan dan keinginan mereka dengan menciptakan, menawarkan, dan bertukar sesuatu yang bernilai satu sama lain. Secara umum pemasaran dapat diartikan sebagai suatu proses sosial yang merancang dan menawarkan sesuatu yang menjadi kebutuhan dan keinginan dari pelanggan dalam rangka memberikan kepuasan yang optimal kepada pelanggan (Arief, 2012:6).

Jadi, hubungan antara pemasaran dengan komunikasi merupakan hubungan yang sangat erat. dapat ditarik kesimpulan bahwa komunikasi pemasaran adalah komunikasi yang dilakukan oleh suatu instansi dengan cara tatap muka ataupun bermedia yang sifatnya membujuk serta membantu konsumen dalam mengambil keputusan untuk melakukan pembelian dalam usaha meningkatkan pendapatan dan jasa.

Menurut Burkat dan Medlik (2001:50) kegiatan pokok yang dapat dilakukan oleh suatu organisasi pariwisata diantaranya adalah:

1. Melakukan koordinasi dalam menyusun strategi pengembangan dan perencanaan pemasaran pariwisata didaerahnya dengan melibatkan pihak-pihak terkait dengan kegiatan pariwisata di daerah itu.

2. Mewakili kepentingan daerah dalam pertemuan-pertemuan yang menyangkut kepentingan pengembangan wisata, baik ditingkat nasional maupun 
JURNAL JURNALISME

Program Studi Ilmu Komunikasi

Fakultas Ilmu Sosial dan Ilmu Politik

Universitas Malikussaleh
P-ISSN: 2502-048X

E-ISSN: 2807-2537

internasional.

3. Mendorong pembangunan fasilitas dan kualitas pelayanan yang sesuai dengan selera wisatawan yang terdiri dari bermacam-macam segmen pasar.

4. Menyusun perencanaan pemasaran dengan mempersiapkan paket- paket wisata yang menarik bersama dengan perantara, meningkatkan kualitas pelayanan dan penyebarluasan informasi kepada wisatawan secara periodik.

Definisi Marketing Mix Menurut Santon dalam Rusdianto (2014: 12) adalah sebagai kombinasi dari empat variabel kegiatan ini inti dari sistem pemasaran dengan pemasaran yaitu :

\section{1. $\quad$ Product (produk)}

Menurut Pendit (2006: 125), produk wisata adalah barang-barang persedian pariwisata yang disediakan oleh kelompok-kelompok insdustry pariswisata sebagai kebutuhan yang dikehendaki oleh wisatawan, baik dalam hubungan sentra maupun objek sentra, baik yang bersifat material maupun non material.

Berdasarkan pengertian tersebut, maka produk wisata dapat diartikan sebagai segala sesuatu yang dikonsumsi oleh wisatawan baik berupa barang berwujud (tangible) maupun tidak berwujud (intangible) untuk memenuhi keinginan dan kebutuhannya mulai dari meninggalkan tempat tinggalnya menuju destinasi sampai kembali lagi ketempat tinggalnya.

2. Price (harga)

Tjiptono (2008) menyatakan bahwa harga dapat digunakan dengan beberapa istilah, misalnya tarif, sewa, bunga, premium, komisi, upah, gaji, dan sebagainya. Dari sudut pandang pemasaran, harga adalah satuan moneter atau ukuran lainnya (termasuk barang dan jasa) yang ditukarkan agar memperoleh hak kepemilikan atau penggunaan suatu barang atau jasa. Harga merupakan satu-satunya unsur bauran pemsaran yang memberikan pemasukan atau pendapatan bagi perusahaan, sedangkan ketiga unsur lain nya adalah (produk, distribusi, dan promosi) menyebabkan timbulnya biaya (pengeluaran). Disamping itu harga merupakan unsur bauran yang bersifat fleksibel, artinya dapat diubah dengan 
JURNAL JURNALISME

Program Studi Ilmu Komunikasi

Fakultas Ilmu Sosial dan Ilmu Politik

Universitas Malikussaleh
P-ISSN: 2502-048X

E-ISSN: 2807-2537

cepat Kotler, (1997). Price ialah harga dari berbagai product yang tersedia pada obyek wisata dengan ketentuan harga harus memadai, tercatat atau terbukti dan tidak selalu berubah.

3. Place (tempat)

Place (tempat) menurut Alma, (2003) berarti kemana tempat/lokasi yang dituju, bagaimana saluran distribusinya, berapa banyak saluran, dan kondisi para penyalur yang diperlukan. Kotler\&Amstrong (1997) mengungkapkan bahwa saluran distribusi adalah suatu perangkat organisasi yang saling tergantung dalam menyediakan saru produk atau jasa untuk digunakan atau dikonsumsi oleh konsumen atau pengguna bisnis. Sedangkan Kotler (1997) mendefinisikan saluran distribusi adalah serangkaian organisasi yang saling tergantung dan terlibat dalam proses untuk menjadikan suatu produk atau jasa siap digunakan untuk konsumsi.

Menurut Kotler (1997) saluran pemasaran melaksanakan tugas memindahkan barang dari produsen ke konsumen. Hal ini mengatasi kesenjangan waktu, tempat dan pemilihan yang memisahkan barang dan jasa dari orang-orang yang membutuhkan atau menginginkannya. Place ialah tempat atau segala sesuatu yang dilaksanakan pada obyek wisata yang menyebabkan wisatawan ingin berkunjung. Misalnya, Pameran, atau obyekobyek pendukung kunjungan wisatawan.

\section{Promotion (promosi)}

Promosi merupakan salah satu faktor penentu keberhasilan suatu program pemasaran. Tjiptono (2008) mengungkapkan bahwa promosi adalah semua kegiatan yang dimaksudkan untuk menyampaikan atau mengkomunikasikan suatu produk kepada pasar sasaran, untuk memberi informasi tentang keistimewaan, kegunaan dan yang paling adalah tentang keberadaannya, untuk mengubah sikap ataupun untuk mendorong orang-orang supaya bertindak.

Promosi adalah pelaksanaan upaya pemasaran, Siswantoro (2004:56). Promosi pariwisata harus dilaksanakan secara selaras dan terpadu, baik di dalam negeri maupun diluar negeri. Apabila dalam promosi ini dapat berhasil maka akan banyak investor yang 
JURNAL JURNALISME

Program Studi Ilmu Komunikasi

Fakultas Ilmu Sosial dan Ilmu Politik

Universitas Malikussaleh
P-ISSN: 2502-048X

E-ISSN: 2807-2537

berani menambahkan modal dalam pengembangan tempat wisata yang beropersai.

\section{Metode Penelitian}

Penelitian ini menggunakan pendekatan kualitatif dengan tipe penelitian deskriptif, dengan maksud untuk memperoleh gambaran yang mendalam mengenai Promosi Objek Wisata Pante Pangah Gampong Ie Rhob Dalam Meningkatkan Kunjungan Wisatawan. Metode kualitatif dapat digunakan untuk mengungkapkan dan memahami sesuatu dibalik fenomena yang sedikit pun belum diketahui. Metode ini juga dapat digunakan untuk mendapatkan wawasan tentang suatu yang baru sedikit diketahui. Demikian pula metode kualitatif dapat memberi rincian yang kompleks tentang fenomena yang sulit diungkapkan oleh metode kuantitatif Stauss dan Corbin (2007: 5) dalam Fajriah (2016: 32).

\section{Hasil Penelitian dan Pembahasan}

\section{Ggambaran Umum Lokasi Penelitian}

Gampong Ie Rhob merupakan salah satu daerah yang berada dalam kawasan

Kecamatan Gandapura Kabupaten Bireuen Propinsi Aceh. Akses jalan menuju Gampong Ie Rhob Sudah di rabatbeton hingga memudahkan untuk menuju tempat wisata. Gampong Ie Rhob berbatasan dengan batas - batas wilayah sebagai berikut:

-Sebelah Utara : Berbatasan dengan Selat Malaka Kecamatan Gandapura

-Sebelah Timur : Berbatasan dengan Sungai Kr. Mane Kecamatan Muara Batu

-Sebelah Barat : Berbatasan dengan Desa Alu Mangki Kecamatan Gandapura

-Sebelah Selatan : Berbatasan dengan Desa Alu Mangku

Kecamatan Gandapura

Jarak antara Gampong Ie Rhob dari Ibu kota Kecamatan Gandapura 1,5 km dan jarak antara Gampong Ie Rhob dengan Kabupaten Bireuen 23 km. Gampong Ie Rhob terletak di daerah yang strategis karena letaknya yang berada di kelilingi oleh tambak dan pantai yang bersebelahan dengan Gampong Lainnya. Akses menuju daerah ini bisa dikatakan sangat baik, meski jalannya hanya rabat baton daerah ini mudah dilalui baik dengan kendaraan bermotor, angkatan umum dan lainnya.

Sebagai salah satu kawasan wisata berdasarkan karakteristik wisatawan di objek 
JURNAL JURNALISME

Program Studi Ilmu Komunikasi

Fakultas Ilmu Sosial dan Ilmu Politik

Universitas Malikussaleh
P-ISSN: 2502-048X

E-ISSN: 2807-2537

Wisata Pante Pangah dan sebagainya yang tersebar di sepanjang pantai, di kawasan area pemukiman penduduk lokal. Objek Wisata Pante Pangah juga menyediakan fasilitas umum seperti mushala, kedai kecil yang di desain sedemikian rupa disepanjang pantai pante pangah juga pondok yang terbuka untuk pengunjung disana juga terdapat waterboom mini untuk pemandian anak kecil. Objek Wisata Pante Pangah merupakan salah satu kawasan yang namanya cukup dikenal oleh pengunjung di seluruh daerah khususnya bagi pengunjung. Gampong Ie Rhob mulai dikenal sebagai tempat wisata semenjak mulai berkembangnya Wisata Pante Pangah. Gampong Ie Rhob yang dulunya adalah desa nelayan dan perikanan mengalami perkembangan yang sangat pesat saat pengunjung tertarik degan keindahan pantai, dengan deburan ombak yang memukai dan bisa menikmati matahari terbenam yang sangat indah.

Sumber daya Gampong yang mampu dikelola dengan baik merupakan salah satu jalan menuju kemandirian Gampong dan merupakan jaminan pembangunan yang berkelanjutan. Untuk itu Gampong Ie Rhob akan mengindentifikasikan semua potensi yang mampu memberikan nilai terhadap pembangunan gampong dengan harapan dapat meningkatkan kesejahteraan masyarakat. Dari potensi sumber daya alam Gampong Ie Rhob memiliki areal pertambakan, pesisir pantai yang indah, dan memiliki potensi alam yang baik untuk dikembangkan. Sedangkan dari sumber daya ekonomi Gampong Ie Rhob banyak memiliki areal pertambakan dan pertanian seperti persawahan dan perkebunan. Dengan mata pencaharian utama masyarakat adalah dari hasil pertambakan dan pertanian, sehingga sumber daya ekonomi Gampong Ie Rhob berasal dari tambak dan pertanian. (Profil Gampong Ie Rhob 2018s/d2024).

\section{Promosi Objek Wisata Pante Pangah Gampong Ie Rhob Kecamatan Gandapura Dalam Meningkatkan Kujungan Wisatawan}

Berdsarkan hasil penelitian yang diperoleh peneliti, pengelola wisata Pante Pangah sebagai salah satu sarana penunjang pemenuhan kebutuhan wisatawan, mempunyai peran dalam penyediaan dan penyebarluasan informasi untuk dapat menarik minat wisatawan atau meningkatkan kunjungan wisatawan. Dalam kegiatannya, pengelola wisata Pante 
JURNAL JURNALISME

Program Studi Ilmu Komunikasi

Fakultas Ilmu Sosial dan Ilmu Politik

Universitas Malikussaleh
P-ISSN: 2502-048X

E-ISSN: 2807-2537

Pangah mengadakan promosi wisata yang bertujuan untuk memperkenalkan dan menginformasikan tempat wisata sehingga dapat menciptakan simpati dan daya tarik mengunjung.

Pada dasarnya segala tingkah laku manusia dalam berinteraksi dengan orang lain itu merupakan komunikasi melingkupi objek yang tidak terbatas dari seluruh kehidupan manusia. Komunikasi merupakan pengaruh yang sangat besar bagi perkembangan dan ilmu pengetahuan dalam dunia usaha maupun bisnis.

Dalam komunikasi pemasaran tidak saja alat untuk melakukan kontak hubungan dengan para wisatawan yang berkunjung, akan tetapi komunikasi pemasaran juga sebagai alat untuk melakukan kontak hubungan dengan para wisatawan atau calon wisatawan akan berkunjung. Akan tetapi, komunikasi pemasaran juga sebagai alat untuk menjembatani yang berhubungan yang akan berhubungan dengan berbagai pihak yang akan berkepentingan terhadap suatu produk. Strategi pemasaran pada dasarnya merupakan kegiatan yang harus dilakukan oleh seorang pemasar dapat menarik perhatian wisatawan untuk berkunjung dan memenuihi kebutuhan, keinginan dan permintaan wisatawan.

Wisata Pante Pangah yang dikenal dengan destinasi wisata keluarga, indah, aman, nyaman dan islami yang dikelola oleh pengelola wisata Pante Pangah dan kepala dinas pariwisata dalam membangkitkan objek wisata Pante Pangah untuk berusaha semaksimal mungkin untuk meningkatkan kualitas wisata Pante Pangah. Usaha yang dilakukan adalah dengan surve langsung kelapangan melihat perkembangan dan kekurangan terhadap objek wisata dan memantau langsung hal-hal terbaru untuk kemajuan wisata.

Dari hasil banding data tahunan yang terdapat pada pengelola wisata Pante Pangah pada tahun 2019 dengan saat ini terlihat bahwa jumlah pengunjung yang berwisata yang mengunjungi objek wisata Pante Pangah mengalami penaikan dan penurunan setiap tahunnya.

Adapun hubungan model AIDA dalam menagalisis Bauran Pemasaran $4 \mathrm{P}$ yaitu untuk menganalisis sejauh mana komunikasi pemasaran yang telah dilakukan oleh pengelola wisata Pante Pangah, serta efek pada peningkatan dan penurunan pengunjung 
JURNAL JURNALISME

Program Studi Ilmu Komunikasi

Fakultas Ilmu Sosial dan Ilmu Politik

Universitas Malikussaleh
P-ISSN: 2502-048X

E-ISSN: 2807-2537

yang datang. Dengan model ini dapat mengukur sejauh mana peran dan komunikasi pemasaran yang telah dilakukan oleh pengelola wisata Pante Pangah terkait perkembangan wisata.

Model AIDA sangat membantu pengelola wisata Pante Pangah dalam memproses mempromosikan pariwisata yang ada di karenakan model ini dapat menjelaskan bagaimana pengelola wisata Pante Pangah ini memperhatikan hingga menghasilkan tindakan dan bagaimana informasi yang didapat oleh masyarakat dan pengunjung wisata. Model AIDA memiliki tahapan yang sangat spesifik dan terarah mulai dari perhatian hingga tindakannya. Adapun bauran pemasara $4 p$ yang dianalisis dengan model AIDA yaitu:

1. Produk (product) sudah termasuk dalam tahapan tindakan (action), produk pariwisata selama ini telah diberikan perhatian khusus dari pengelola wisata Pante Pangah. Yang pengelola telah membuka usaha dalam memenuhi kebutuhan wisatawan. Namun, kendala yang dialami sekarang adalah wisata Pante Pangah belum terekspos secara menyeluruh untuk dapat diketahui oleh masyarakat luar kota, hal ini ditunjukkan dari hasil pengunjung yang datang mengujungi wisata Pante Pangah belum mengetahui secara keseluruhan wisata Pante Pangah. Sehingga menghambat pariwisata untuk berkembang. Untuk itu perlu suatu perhatian khusus dalam memperkenalkan wisata agar dapat meningkatkan minat kunjung setiap tahunnya.

2. Harga (price) sudah mencapai tahap perhatian (attention), kebijakan dari pengelola wisata Pante Pangah menerima respon yang baik dari masyarakat serta pengunjung wisatawan yang berkunjung ke wisata Pante Pangah. Hal ini terlihat dari tidak adanya pemungutan untuk kunjungan wisata Pante Pangah sebagai bentuk dari kebijakan atas keringanan pengunjung yang hendak mengunjungi wisata Pante Pangah. Namun hal tersebut tidak berlaku untuk biaya parkir, biaya sewa pondok, tapi tidak menjadi masalah, setidaknya sudah mengurangi beban bagi wisatawan untuk menikmati wisata yang ada. Hal ini tentu akan menaikkan nilai kunjung dari wisata Pante Pangah agar lebih menarik perhatian pengunjung agar datang. 
JURNAL JURNALISME

Program Studi Ilmu Komunikasi

Fakultas Ilmu Sosial dan Ilmu Politik

Universitas Malikussaleh
P-ISSN: 2502-048X

E-ISSN: 2807-2537

3. Tempat (place) tempat dalam model ini telah masukn pada tahap minat (interest) dan hasrat (desire), wisata yang bagus berarti memiliki fasilitas-fasilitas yang memadai juga untuk penunjang dalam menikmati wisata Pante Pangah. Pengelola wisata Pante Pangah sudah meningkatkan fasilitas yang ada untuk kenyamanan pengunjung. Adapun fasilitas - fasilitas yang terdapat dilokasi wisata Pante Pangah yaitu taman bermain anak-anak, toiet umum, mushalla dan pondok- pondok. Namun, ada beberapa kekurangan yang menghambat fasilitas yang ada. Jalannya yang agak sempit dan tidak bisa di lintasi ketika pas air pasang menjadi kendala, tetapi di balik kekurangan tersebut, wisata pantai Pante Pangah sangat bersih dan indah. Hal ini di dukung dengan adanya tempat sampah di setiap sudut wisata yang mudah dijangkau oleh pengunjung.

\section{Promosi}

Promosi dalam model ini sudah masuk pada tahap tindakan (action) dimana proses promosi selama ini telah dilakukan semaksimal mungkin dengan menggunakan mediamedia yang dianggap cukup mampu mempromosikan objek wisata Pante Pangah. Adapun media yang digunakan cukup beragam yaitu:

1. Event

Event merupakan sebuah rangkaian acara dalam bentuk promosi suatu produk kepada khalayak dengan tujuan agar khalayak dapat lebih mengenal suatu produk. Selama event yang ada di wisata Pante Pangah diadakan, hal inilah yang menjadi wisata Pante Pangah semakin di depan. Dalam kegiatan event dapat kita lihat pengelola wisata menjadi informan yang akan memberikan informasi pada saat kegiatan event dan akan disebarluaskan oleh khalayak.

\section{Iklan}

Iklan merupakan berita atau pesan untuk membujuk dan mendorong orang agar tertarik pada barang atau pun jasa yang ditawarkan, iklan bisa di promosikan melalui media periklanan seperti, televisi, radio, koran dan media internet. Akan tetapi masih ada kekurangan yang terdapat dalam mempromosikan objek wisata terdapat beberapa akun yang mempromosikan objek wisata Pante Pangah tapi bukan akun sah dari pengelola 
JURNAL JURNALISME

Program Studi Ilmu Komunikasi

Fakultas Ilmu Sosial dan Ilmu Politik

Universitas Malikussaleh
P-ISSN: 2502-048X

E-ISSN: 2807-2537

wisata.Dalam komunikasi pemasaran promosi iklan masuk pada tahap publikasi dimana publikasi merupakan bentuk kegiatan promosi yang menggunakan media cetak,online dan sebagainya.

3. Instagram

Instagram merupakan salah satu media sosial yang sangat berpengaruh dalam hal mempromosika dan juga berpengaruh terhadap pemasaran, dapat kita lihat pengelola wisata Pante Pangah dalam mempromosikan objek wisata Pante Pangah dalam meningkat kan kunjungan wisatawan. Menggunakan media sosial Instagram untuk promosi, akan tetapi masih ada kekurangan yang terdapat dalam mempromosikan objek wisata menggunakan instagram pihak pengelola disini kurang berperan aktif dalam mempromosikan objek wisata terdapat dari beberapa akun yang mempromosikan objek wisata tetapi tidak akun sah dari pengelola wisata Pante Pangah. Dalam komunikasi pemasaran instagram sudah termasuk dalam bentuk bentuk promosi yang di publikasikan melalui media sosial.

\section{Pemasaran Langsung/ Direct marketing}

Dengan berkembangnya sarana transportasi dan komunikasi maka kontak transaksi penjual dan pembeli menjadi lebih mudah. Hal inilah yang memunculkan adanya direct marketing atau pemasaran langsung. Direct marketing adalah upaya perusahaan atau organisasi untuk berkomunikasi secara langsung dengan calon pelanggan yang dimaksud menimbulkan tanggapan atau transaksi penjualan.

Dalam pemasaran langsung terdapat salah satu strategi yaitu word of mouth atau pemasaran dari mulut ke mulut ini yang dilakukan pengelola wisata Pante Pangah dengan memanfaatkan teman, kerabat dan sebagainya, dimana tujuannya adalah untuk menarik wisatawan untuk berkunjung ke wisata Pante Pangah.

\section{Hambatan-Hambatan Dalam Pengembangan Wisata Pante Pangah Gampong Ie Rhob KecamataN Gandapura Dalam Meningkatkan Kunjungan Wisatawan}

Wisata pante pangah merupakan wisata yang baru dibangun di Gampong Ie Rhob kecamatan gandapura. Wisata Pante Pangah memiliki keindahan dan menarik serta 
JURNAL JURNALISME

Program Studi Ilmu Komunikasi

Fakultas Ilmu Sosial dan Ilmu Politik

Universitas Malikussaleh
P-ISSN: 2502-048X

E-ISSN: 2807-2537

mempesona untuk dikunjungi wisatawan, baik luar maupun dalam negeri.

Potensinya sangat menjanjikan untuk menggaet wisatawan mancanegara dan dalam negeri. Apalagi, didukung dengan keindahan pantainya. Sungguh mempesona mata pengunjung kalau di garap secara profesional. Kalau boleh dikatakan tidak kalah dengan wisata-wisata di daerah lain.

Sayangnya, wisata pante pangah tidak mempunyai banyak anggaran untuk membenahi wisata Pante Pangah. Dana BUMG jelas tidak akan mencukupi untuk membenahi atau menggarap wisata Pante Pangah. Hambatan dalam pengembangan wisata Pante Pangah yang terbesar adalah dana yang tidak cukup mengembangkan pariwisata. Selain itu, hambatan dalam pengembangan yang dihadapi dalam pemasaran yang dilakukan menggunakan media promosi, oleh pengelola wisata Pante Pangah ialah belum tercapainya salah satu cara mempromosi yang telah di sosialisasikan dan akan disosialisasikan kembali di tahun mendatang mengenai pengembangan wisata melalui iklan.

Bukan hanya itu disini pengelola wisata Pante Pangah juga sering menghadapi hambatan mengenai sistem transportasi yang belum memadai sering kali terjadi sebagai kendala jalan yang sempit yang menyebabkan tidak mudah masuknya ketempat wisata di tambah dengan jika air laut pasang di jalan masuk akan ada air yang tergenang dijalan ditambah dengan jalan yang terbuat dari tanah pasir sehingga orang yang ingin masuk ke tempat wisata harus putar balik harus masuk lewat jalan keluar atau jalur evakuasi, sehingga kadang harus desak-desakan dijalan atau pun macet menambah kendala tersendiri untuk pengembangan wisata Pante Pangah.

Disamping itu juga kendala lain yaitu pengelola wisata Pante Pangah sendiri juga dalam upaya mempromosikan objek wisata tersebut berbagai kendala semakin meningkat, misalnya kurangnya area parkir sehingga pemuda membuat lapak lain untuk membuat area parkir sehingga membuat masyarakat yang berkunjung menjadi agak resah di karenakan area parkir jaug dari pantauan masyarakat takut akan kehilangan sepeda motornya walaupun ada tukang parkir. Dalam melakukan pemasaran tentunya terus berupaya 
JURNAL JURNALISME

Program Studi Ilmu Komunikasi

Fakultas Ilmu Sosial dan Ilmu Politik

Universitas Malikussaleh
P-ISSN: 2502-048X

E-ISSN: 2807-2537

menciptakan sinergi agar promosi dapat berjalan dengan baik dan mendapatkan respon yang bak, diperlukan kesinambungan atau koordinasi antar semua elemen komunikasi (iklan, tempat, pemasaran langsung, pemasaran dari mulut kemulut dan lain-lain). Hal ini bertujuan untuk menghasilkan citra merek yang kuat sehingga mampu mengekarkan masyarakat.

Maka dari itu setiap bagian-bagian tersebut harus terkontrol, akan tetapi mengontrol objek wisata Pante Pangah memang tidak lah mudah, dengam bermacam-macam masalah yang terjadi di lapangan itu merupakan kendala yang harus dihadapi dengan kerjasama. Rendahnya, sumber daya manusia, terutama tenaga yang tampil dalam hal ini adalah manajemen dibidang wisata. Merupakan hambatan dalam pengembangan wisata paling sering meuncul terutama pada negara-negara berkembang, termasuk Indonesia. Sumber daya manusia merupakan komponen utama dalam penuntun, terutama dalam menjalankan manajemen pemasaran.

Komonikasi pemasaran memegang peran penting setiap pemasaran terutama dalam mempromosikan objek wisata Pante Pangah Gampong Ie Rhob Kecamatan Gandapura dalam meningkat kan kunjungan wisatawan manupun wisatawan mancanegara. Semakin banyak mempromosikan mengiklankan maka semakin banyak juga masyarakat yang tau akan objek wisata Pante Pangah. Penerimaan masyarakat baik di sekitar maupun di luar daerah objek wisata Pante Pangah ini tidak terlepas dari kemampuan promosi yang dilakukan oleh pengelola wisata dalam menyusun promosi wisata. Hal ini bisa terwujud karena adanya promosi yang tepat yang dilakukan oleh pihak pengelola wisata. Promosi objek wisata Pante Pangah melibatkan penggunaan media-media komunikasi yang semakin efektif dan informatif, sehingga masyarakat dengan mudah mendapatkan informasi mengenai objek wisata Pante Pangah. Kebutuhan akan wisata untuk menghilangkan jenuh merupakan hal yang akan dilakukan setiap masyarakat, dan promosi wisata merupakan salah satu cara yang tepat untuk memberikan informasi kepada masyarakat.

Dari hasil yang diperoleh, maka pengelola wisata mempunyai solusi kebijakan 
JURNAL JURNALISME

Program Studi Ilmu Komunikasi

Fakultas Ilmu Sosial dan Ilmu Politik

Universitas Malikussaleh
P-ISSN: 2502-048X

E-ISSN: 2807-2537

mengenai hambatan-hambatan dalam pengembangan wisata yang dihadapi dalam promosi untuk menuju yang lebih baik dan menarik, mengontrol objek wisata dan lebih baik dan menarik mengontrol anggaran dana yang lebih baik lagi, dan menjalin hubungan dengan masyarakat untuk menimbulkan rasa ingin membangkitkan objek wisata Pante Pangah menjadi yang lebih kreatif, inovatif, meanarik perhatian dan banyak dikunjungi oleh wisatawan karena itu juga menjadi aset penambahan ekonomi masyarakat dan menimbulkan lapangan bagi penduduk setempat seperti penjaga parkir dan juga pedagang. Berdasarkan model AIDA yang menjadi tolak ukur bagi penguji melihat sejauh mana promosi yang dilakukan oleh pengelola wisata Pante Pangah, berdasarkan hambatanhambatan dalam pengembangan wisata Pante Pangah yang di hadapi pleh pengelola wisata pante pangah masuk pada tahap citra/pemahaman, karena pengelola wisata pante pangah masih terus mencoba untuk menyakinkan dan melakukan berbagai cara agar promosi wisata Pante Pangah semakin berkembang dan dapat dikenal masyarakat luas.

Namun, dari keseluruhan pelaksanaan promosi yang dilakukan oleh pengelola wisata pante pangah sebagai individu yang mempromosikan wisata sudah masuk pada tahap perhatian (attention) dan tindakan (action). Karena pengelola telah melakukan promosi pariwisata yang telah ada. Namun, untuk saat ini bagaimana respon masyarakat untuk hasil kerja yang dilakukan pengelola.

\section{Kesimpulan}

Promosi objek wisata yang dilakukan oleh pengelola wisata Pante Pangah untuk saat ini belum cukup maksimal dapat dilihat pada bab sebelumnya. Dalam memasarkan untuk mempromosikan wisata pengelola menggunakan Bauran pemasaran $4 \mathrm{p}$ atau Marketing Mix dan menganalisis menggunakan model AIDA yang terdiri dari produk yang saat ini telah mencapai tingkat perhatian (attention). Harga telah mencapai tingkat minat (interest) selanjutnya tempat yang telah mencapai tahap minat (interest) dan hasrat (desire) dan yang paling terakhir promosi yang telah masuk pada tahap kegiatan (Action). Adapun tujuan promosi wisata bertujuan untuk memperkenalkan dan mempromosikan objek wisata Pante Pangah sehingga dapat menciptakan daya tarik pengunjung. Namun, 
JURNAL JURNALISME

Program Studi Ilmu Komunikasi

Fakultas Ilmu Sosial dan Ilmu Politik

Universitas Malikussaleh
P-ISSN: 2502-048X

E-ISSN: 2807-2537

masih banyak kekurangan yang dihadapi pengelola terkait kurang update media sosial dari pengelola wisata sendiri dan kurangnya budget biaya untuk promosi.

\section{Daftar Pustaka}

Abidin, Yusuf Zainal. (2015), Manajemen Komunikasi. Bandung: CV PUSTAKA SETIA.

Abubakar, Rusydi (2018), Manajemen Pemasaran. Bandung: Alfabeta. Abdurrahman, Herdiana Nana. (2015). Management Strategi Pemasaran. Bandung : Cv Pustaka Setia.

Aditiawarman, Mac, dkk. (2019), Hoax Dan Hate Speech Di Dunia Maya. Lembaga Kajian Aset Budaya Indonesia Tonggak Tuo.

Arief, Al M. Nur Rianto (2012). Dasar-Dasar Pemasaran Bank Syariah. Bandung: Alfabeta.

Angipora, P Marius. (2002). Dasar-Dasar Pemasaran Edisi Kedua. Jakarta : PT Raja Grafindo Persada.

Ardianto, Elvinaro (2011). Metode Penelitian Untuk Public Relatios Kuantitatif dan Kualitatif. Bandung : Remaja Rosdakarya Bandung.

Arikunto, Suharsimim H. (2006). Dasar-dasar evaluasi. Cet VI. Jakarta: PT Bumi Askara.

Banurea, Netti. (2019). Strategi Komunikasi Pemasaran Dinas Pemuda Olahraga Dan Pariwisata Kota Subulussalam Dalam Mempromosikan Objek Wisata. Skripsi. Universitas Malikussaleh.

Burkat, A. J and S. Medlik.(2001). Tourism: Past, Present And Future. London United Kindom.

Cangara, Hafied. (2014). Pengantar Ilmu Komunikasi. Jakarta: PT RajaGrafindo Persada.

Effendy, Onong Uchana. (2003). Ilmu komunikasi teori dan praktek. Cetakan kesembilan belas. Bandung. PT Remaja Rosdakarya.

Fajriah, Leni. (2016). Strategi Komunikasi Pemasaran (Promosi) Dinas Perhubungan, Pariwisata, dan Kebudayaan Kota Lhokseumawe Dalam Menyebarluaskan Informasi Wisata Tahun 2014-2015. Skripsi. Universitas Malikussaleh Aceh Utara.

Hakim, Luchman. Wilopo, dan Khotimah Husnul. (2017). Strategi Pengembangan Destinasi Pariwisata Budaya ( Studi Kasus Pada Kawasan Situs Trowulan Sebagai Pariwisata Budaya Unggulan di Kabupaten Mojekerto). Universitas Brawijaya 
JURNAL JURNALISME

Program Studi Ilmu Komunikasi

Fakultas Ilmu Sosial dan Ilmu Politik

Universitas Malikussaleh
P-ISSN: 2502-048X

E-ISSN: 2807-2537

Malang.

Khatijah, Arfianti Siti. (2017). Aktivitas Public Relations Untuk Meningkatkan Daya Tarik Wisata Dan Pendidikan Di Museum H. M. Soeharto. Universitas Negeri Yogyakarta.

Kotler, P. (1997). Prinsip -prinsip Pemasaran. Edisi . Jilid 1. Jakarta : Erlangga Kotler \& Keller. (2012). MarketingManagemet. Edisi 14. Global Edition. Neuw Jersey. Pearson Education.

Mahendra, Bimo. (2017). Eksistensi Sosial Remaja Dalam Instagram (Sebuah Perpektif Komunikasi). Jurnal.

Misdriyana, Muthia. (2017). Strategi Komunikasi Pemasaran Dinas Pariwisata Pemerintah Kota Makassar Dalam Meningkatkan Kunjungan Wisatawan Mancanegara Di Kota Makasaar. Skripsi. Universitas Islam Negeri Alauddin Makassar.

Mukarom, Zainal dan Laksana, Muhibudin Wijaya. (2015). Manajemen Public Relation panduan efektif pengelolaan hubungan masyarakat Bandung : Pustaka Seti.

Moleong, Lexy. (2017). Metode Pnelitian Kualitatif. Bandung: Remaja Rosada Karya.

Morissan. (2010). Periklanan Komunikasi Pemasaran Terpadu. Jakarta : Penerbit. Kencana

Nurjannah, dkk. (2017). Model Perencanaan Komunikasi Program Corparatesocial responsibility (CSR) PT. Chevron Pacific Indnesia. Jurnal. Universitas Riau.

Pendit, (2006) Ilmu Pariwisata “(Sebuah Pengantar Perdana”, Jakarta: Gramedia.

Pitana, Gde I \& Gayatri, G. Putu (2005). Sosiologi Pariwisata. Yogyakarta: Andi Offset.

Putra, Laksana Effid. (2015). Aktivitas Public Relations Untuk Meningkatkan Daya Tarik Wisata, Pendidikan Dan Budaya Di Museum Benteng Vredeburg Daerah Istimewa Yogyakarta. Skripsi. Universitas Negeri Yogyakarta.

Rachman, Rio. (2018). Kegiatan Promosi Desa Wisata Banyubiru Dalam Menarik Minat Wisatawan. Skripsi. Universitas Sultan Ageng Tirtayasa.

Rachman, Siam Riezky. (2018). Peran Humas Kebudayaan Dan Pariwisata Kota Tanggerang Dalam Mempromosikan Wisata Situ Cipondoh Di Era New Media (Studi Kasus Pengelolaan Website, Instragram Dan Tanggerang TV). Skripsi. Universitas Sultan Ageng Tirtayasa. 
JURNAL JURNALISME

Program Studi Ilmu Komunikasi

Fakultas Ilmu Sosial dan Ilmu Politik

Universitas Malikussaleh
P-ISSN: 2502-048X

E-ISSN: 2807-2537

Revida, Erika dkk. (2020). Pengantar Pariwisata. Yayasan Kita Menulis. Rencana Pembangunan Jangka Panjang Menengah Gampong Ie Rhob Tahun 2018-2024.

Rusdianto, Even Ahmad. (2014). Analisis Strategi Promosi Pada Taman Pintar Di Yogyakarta. Skripsi. Universitas Negeri Yogyakarta.

Ruslan, Rosady. (2005). Manajemen Public Relations \& Media Komunikasi. Jakarta: Pt Raja Grafindo Persada.

Saebani, Beni Ahmad. (2008). Metode Penelitian. Bandung: CV Pustaka Setia. Somad, Rismi dan Priansa, Juni, Donni. (2014). Manajemen Komunikasi Mengembangkan Bisinis Beriorientasi Pelanggan. Bandung: Alfabeta.

Subroto, Budiarto. (2011). Pemasaran Industri (Business Tobusiness Marketing). Yogyakarta: Andi.

Suganda, Delfi. (2018). Fungsi Strategi Tuha Peut Dalam Melakukan Pengawasan Dan Pencegahan Korupsi Dana Gampong. jurnal. UIN Ar-Raniry, Banda Aceh.

Sukmadi, (2016). InovasiDan Kewirausahaan Edisi Paradigma Baru Kewirausahaan. Bandung.

Tjiptono, Fandy (2008). Strategi Pemasaran. Edisi Ketiga. Yogyakarta: Andi. Tripa, Sulaiman. (2019). Rekontruksi Pemerintahan Gampong. Banda Aceh: Bandar Publishing.

Wolah, Ferni fera Ch. (2016). Peranan Promosi Dalam Meningkatkan Kunjungan Wisatawaan Di Kabupaten Poso. Jurnal.

Yandiaznuri dkk. (2018) Efektivitas Promosi Melalui Instragram Pada Umkm Sektor Makanan Dan Minuman Di Kota Pekan Baru. Jurnal. Universitas Lancang Kuning 